\title{
Vector Transmission of a Plant-Pathogenic Bacterium in the Arsenophonus Clade Sharing Ecological Traits with Facultative Insect Endosymbionts
}

\author{
Alberto Bressan, Olivier Sémétey, Joel Arneodo, Jeannine Lherminier, and Elisabeth Boudon-Padieu
}

First, second, third, and fifth authors: Biologie et écologie des bactéries du phloème, UMR Plante Microbe Environnement INRA-CNRSUniversité de Bourgogne, BP 86510-21065 DIJON Cedex France; and fourth author: Centre de microscopie électronique, UMR Plante Microbe Environnement INRA-CNRS-Université de Bourgogne, BP 86510-21065 DIJON Cedex.

Current address of first author: Department of Plant and Environmental Protection Sciences, University of Hawaii at Manoa, Honolulu 96822 .

Current address of third author: CONICET, Instituto de Microbiología y Zoología Agrícola-INTA, CC 25-1712 Castelar, Argentina.

Accepted for publication 24 July 2009.

\begin{abstract}
Bressan, A., Sémétey, O., Arneodo, J., Lherminier, J., and BoudonPadieu, E. 2009. Vector transmission of a plant-pathogenic bacterium in the Arsenophonus clade sharing ecological traits with facultative insect endosymbionts. Phytopathology 99:1289-1296.

The planthopper Pentastiridius leporinus (Hemiptera: Cixiidae) is the major vector of a nonculturable plant-pathogenic $\gamma-3$ proteobacterium associated with a disease of sugar beet called syndrome "basses richesses" (SBR). The bacterium, here called SBR bacterium, belongs to the Arsenophonous clade, which includes mostly insect-associated facultative symbionts. Assays using field-collected planthopper nymphs and adults were carried out to investigate the interaction of SBR bacterium with the insect vector and its transmission to sugar beet. Fieldcollected planthoppers showed a percentage of infection that averaged from $57 \%$ for early instar nymphs to near $100 \%$ for late instar nymphs and emerging adults. SBR bacterium was persistently transmitted by
\end{abstract}

ABSTRACT

The syndrome "basses richesses" (SBR) is an emerging disease of sugar beet (Beta vulgaris L.) in eastern France associated primarily with a phloem-restricted bacterium, here called SBR bacterium. The bacterium infects systemically roots and foliages (12-14) and reduces the content of sugar in affected roots. Early symptoms of SBR are yellowing and incurvation of old leaves and new growth of central leaves which appear chlorotic, lanceolated, and asymmetrical. Roots have normal size but they contain brown vascular bundles and their sugar content suddenly decreases in the beginning of September (12-14).

Phylogenetic studies based on sequences obtained from the $16 \mathrm{~S}$ rRNA and spoT-spoU-recG genes have demonstrated that SBR bacterium is a member of the $\gamma-3$ proteobacteria and shares high sequence homology with bacteria in the Arsenophonus clade $(29,33)$. The latter clade includes mostly insect-associated bacteria infecting, among others, hemipterans such as whiteflies $(6,37)$, psyllids (19), planthoppers (29), as well as dipterans (8) and hymenopteran wasps (16). Arsenophonus bacteria are reported to colonize insect host-haemocoel $(8,16,17,19)$.

Corresponding author: A. Bressan; E-mail address: bressan@hawaii.edu

* The $\boldsymbol{e}$-Xtra logo stands for "electronic extra" and indicates that the online version contain two figures showing an agarose gel documenting the specificity of primers designed for real-time PCR and the melting curves obtained through real-time PCR.

doi:10.1094/PHYTO-99-11-1289

(C) 2009 The American Phytopathological Society emerging adults. Root-feeding nymphs were able to inoculate SBR bacterium to sugar beet. The bacterium was transmitted vertically from infected parental females to their respective offspring with an average frequency of $30 \%$. Real-time polymerase chain reaction assays on dissected planthopper internal organs revealed a high concentration of the bacterium within male and female reproductive organs and within female salivary glands. SBR-like bacteria were observed through transmission electron microscopy in the cytoplasm of different insect organs including ovaries, salivary glands, and guts with no evidence for cytological disorders. SBR bacterium seems to share common ecological traits of insect-transmitted plant pathogens and facultative insect endosymbionts suggesting it may have evolved primarily as an insect-associated bacterium.

Additional keywords: "Candidatus Phlomobacter fragariae", Cixius wagneri, phloem-limited bacteria.

SBR bacterium is closely related but distinct from the phloemrestricted plant pathogen, "Candidatus Phlomobacter fragariae" (29), which is the main causal agent of marginal chlorosis disease of strawberry $(11,39)$. In France, diseases caused by these two pathogens have different geographical distributions: SBR disease occurs in eastern France while marginal chlorosis disease of strawberry occurs in western France $(9,32)$. In addition, " $C a$. Phlomobacter fragariae" has been detected in strawberry in Japan (34), and SBR bacterium has been detected in sugar beets in Hungary (O. Sémétey, unpublished data) and strawberry affected by marginal chlorosis-like symptoms in Italy (36).

In eastern France, SBR bacterium is spread to sugar beets by a planthopper vector, Pentastiridius leporinus (Hemiptera: Cixiidae) $(12,13,30,31,33)$. "Ca. Phlomobacter fragariae" is spread to plants by means of another cixiid planthopper, Cixius wagneri (China) (9). Furthermore, we have shown that planthoppers from a population of $C$. wagneri captured from sugar beet fields in eastern France were infected by and transmitted SBR bacterium to sugar beet seedlings (5).

No information is available on how these plant-pathogenic $\gamma-3$ proteobacteria are transmitted by and interact with their cixiid planthoppers. As mentioned above, a phylogenetic study has shown that these bacteria are closely related to secondary (also called facultative) symbionts of insects (33). In general, secondary symbionts colonize insect host haemocoel, where they invade various cells and tissues. They are maternally transmitted to the progeny through egg-infection although they maintain the 
potential of being transferred horizontally within and between species $(26,28,37)$. Facultative symbionts, including Arsenophonous bacteria, influence insect fitness in different ways. Some behave as mutualists as they benefit their insect hosts (19) and others are parasitic, such as those that manipulate host reproduction (16).

In Europe, planthoppers in the family Cixiidae are reported as vectors of stolbur phytoplasmas (38), a group of cell wall-less, phloem-restricted parasites of plants affiliated to the class Mollicutes (10). Phytoplasmas are transmitted by phloem-sucking insect vectors in a propagative fashion (20), which implies a latent period between acquisition and inoculation phases and the retention of the infectivity. In general, insects acquire phytoplasmas by feeding on phloem tissue of infected plants. It has been shown for a few leafhopper vectors, that after ingestion, phytoplasmas move into epithelial cells of the midgut and after intracellular multiplication, they enter the haemocoel through the gut epithelium basement membrane (22). Once in the hemolymph, phytoplasma cells may infect a variety of insect internal organs, including Malpighian tubules and fat bodies. However, successful transmission is achieved when phytoplasma cells reach and multiply within the salivary glands and get discharged with the saliva during insect feeding $(22,23)$. In some cases, phytoplasmas have been shown to be transmitted maternally from infected females to their progenies $(18,35)$.

$P$. leporinus has also been shown to transmit stolbur phytoplasma to sugar beet in eastern France (14). However, field surveys have demonstrated that the phytoplasma has a marginal role in the etiology of SBR disease compared with SBR bacterium (32). Additionally, in previous studies, populations of $P$. leporinus were only marginally infected by the phytoplasma $(5,12,31)$.

In France, the planthopper produces a single generation per year and spends most of its life cycle as underground nymphs feeding on host plant roots $(3,4,12,30)$. Insects occur in sugar beet fields and on a cereal crop rotated thereafter, which in most cases is wheat (Triticum sp.) $(3,4)$. While adults colonize, breed, and lay eggs on sugar beets, subterranean nymphs spend the first phase of their development feeding on sugar beet roots, and after completion of the winter diapauses, they develop feeding on winter wheat sown after sugar beet harvest. Thus, adults emerge from wheat fields from the middle of June through the end of July and migrate to colonize neighboring and newly sown sugar beets where they settle to feed and reproduce $(3,4)$. Adult planthoppers are suspected to be infective (e.g., able to inoculate the bacterium) soon after emergence and maintain their potential to inoculate SBR bacterium by feeding on sugar beet foliage for their entire life span (30). Since eggs hatch soon after being laid, emerging nymphs can feed on SBR-infected sugar beet roots throughout the summer time until crop harvest and would have the potential of spreading the bacterium from plants infected by the parental generation and thus contributing to the spreading of the disease while the adult flight is over.

We have carried out a series of experiments attempting to examine the relationship between SBR bacterium and P. leporinus. Because of the difficulty of rearing $P$. leporinus in controlled conditions, we used field insects collected either as adults or as young nymphs during the sugar beet growing period or as late instar nymphs from wheat roots on the same plots in the following spring. To ensure planthoppers were infected by SBR bacterium, sampling was conducted in an area with a high pressure of SBR disease $(31,32)$. In addition, we used previously developed diagnostic polymerase chain reaction (PCR) procedures to detect SBR bacterium in individual insects (31) and inoculated plants (32). We attempted to analyze the evolution of the frequency of SBR bacterium infection during the life cycle of the planthopper; the possible transmission of SBR bacterium by nymphs; the retention of infectivity by emerging adults; and the vertical transmission of the pathogen to the insect progeny. Furthermore, using a quantitative PCR assay, we analyzed the distribution of the bacterium in internal insect organs and attempted to obtain ultrastructural evidence of bacterial colonization through transmission electron microscopy (TEM) observations.

\section{MATERIALS AND METHODS}

Insect sampling. Nymphs and adults of $P$. leporinus were collected in 2005 and 2006 from three fields cultivated to sugar beet and rotated with wheat. Selected fields were located near Chissey village $\left(47^{\circ} 01^{\prime}\right.$ North, $5^{\circ} 42^{\prime}$ East) in the Jura Department (Franche-Comté Region, France). The area experienced high pressures of the SBR disease in the previous years (32). In accordance with the life cycle of the planthopper $(3,4,12,30)$, subterranean nymphs were collected within the sugar beet plantings as early instars (second-to-third) in September before sugar beet harvesting. For sampling, randomly selected soil removals containing plant roots were dug out with a spade, put in a basket, and disaggregated by hand; identified nymphs were collected from soil, confined into tube vials, and transported to a greenhouse facility for biological assays. Post-diapausing fourthto-fifth instar nymphs were similarly collected in June of the following season from the soil of wheat crops that followed the sugar beet plantings. Adults that emerged from the wheat fields were sampled with a D-Vac aspirator (Ventura, CA) before migration to newly sown sugar beet fields. Planthoppers retained in vacuum meshes were segregated from other insect species, put onto caged sugar beet seedlings, and transported to a greenhouse facility for biological assays. To analyze the possible vertical transmission of SBR bacterium to the progeny, females supposed to be gravid were collected as previously described on the second half of July after migration to newly planted sugar beet fields.

Detection of SBR pathogens in insects and plants. Procedures for DNA purification and diagnostic PCR assays for detection of stolbur phytoplasma and of SBR bacterium in insects and test plants were as previously described $(5,31,32)$. For detection of stolbur phytoplasma in planthoppers, amplification was performed with a direct PCR procedure using primers Stol11f3/ Stol11r2 (5). For specific detection of SBR bacterium in insects, we used Alb1/Oliv1 primer pair designed to amplify the internal transcribed spacer region between the $16 \mathrm{~S}$ and 23S rRNA genes of the bacterium. PCR products show a typical fingerprint (31). PCR conditions were as previously described (31). For the detection of stolbur phytoplasma in sugar beet seedlings we used a nested PCR with Stol11f2/Stol11r1 as the first pair of primers, then Stol11f3/Stol11r2 as the second pair of primers. PCR conditions were as previously described (5). For specific detection of SBR bacterium in sugar beet seedlings we used primers pairs Fra5/rp1 following similar PCR conditions described earlier (32). Positive and negative controls were included for all amplification runs and were as previously described (5).

Transmission assays. Sugar beet test plants were potted 50- to 80-day-old seedlings (cv. Brigita) maintained in an insect-proof greenhouse. Transmission assays were performed in a greenhouse with natural light and temperature $\left(26 \pm 5^{\circ} \mathrm{C}\right)$. Sugar beet seedlings were caged with mesh-ventilated PVC cylinders during inoculation tests with planthoppers (either nymphs or adults). Inoculation access periods (IAPs) varied according to the experiments conducted and are reported hereafter. From each caged plant, planthoppers were removed at the end of the given IAP and stored at $-20^{\circ} \mathrm{C}$. Exposed plants were sprayed and drained with Imidacloprid (Admire, Bayer CropScience) and transferred to an insect-proof glasshouse for 3 to 4 months for symptom development. Each assay included sugar beet seedlings not exposed to insects as negative controls. Plants were periodically observed for SBR symptoms, which have been described elsewhere $(13,32)$. All sugar beet seedlings and planthoppers used for transmission 
assays were tested individually for the presence of stolbur phytoplasma and SBR bacterium.

Transmission by nymphs. To analyze whether nymphs transmitted SBR bacterium, 5 to 10 field-collected second-to-third instar nymphs were confined on the soil of caged potted sugar beet seedlings and allowed to feed on plant roots for an IAP of 30 days.

Retention of infectivity. To assess the persistence of SBR bacterium transmission by infected specimens, batches of two (2) emerging adults, males or females collected at the beginning of the flight activity from wheat fields were confined to sugar beet seedlings. At the end of an IAP of 3 days, living insects were transferred to new healthy seedlings whereas dead insects were removed from the cages and stored at $-20^{\circ} \mathrm{C}$. Planthoppers were serially transferred every 3 days until all insects died.

Vertical transmission. Supposedly gravid females collected in sugar beet fields were singly confined to caged potted healthy sugar beet seedlings. Soil in the pot was covered with a $10-\mathrm{mm}-$ thick sponge pad under which females could creep to lay eggs in dark spots. Cages were inspected daily for eggs laid on underside of sponge pad interfacing with the soil. Eggs generally appeared in groups of 20 to $35 \mathrm{kept}$ together by waxy filaments. To ensure that hatching nymphs $\left(\mathrm{F}_{1}\right)$ would not feed on sugar beets where the parental female had fed, all eggs from each nest were periodically collected from soil and moved to mesh-ventilated PVC-cylinders maintained in a dark chamber $\left(23 \pm 1{ }^{\circ} \mathrm{C}\right.$, light $16 \mathrm{~h}$, dark $8 \mathrm{~h}$ ). After oviposition, parental females were stored at $-20^{\circ} \mathrm{C}$ within $1.5-\mathrm{ml}$ tubes while hatching nymphs $\left(\mathrm{F}_{1}\right)$ were supplied twice a week with pieces of healthy sugar beet taproot produced from healthy potted seedlings. For transmission assays, cohorts of surviving offspring at the stage of emerging adults issued from individual parental females were transferred separately from the rearing boxes to caged healthy sugar beet seedlings for an IAP of 20 to 25 days. At the end of the inoculation period, insects were collected from caged plants and frozen at $-20^{\circ} \mathrm{C}$ within $1.5-\mathrm{ml}$ tubes.

Infection of field-collected planthoppers with SBR bacterium and stolbur phytoplasma. Field-collected planthoppers issued from three developmental categories (pre-diapausing second-to-third instar nymphs, post-diapausing fourth-to-fifth instar nymphs, and emerging adults) were tested individually for the presence of stolbur phytoplasma and SBR bacterium. Planthoppers collected from the three sampled fields were considered as independent replications and one-way analysis of variance (ANOVA) followed by a Tukey test for pairwise multiple comparisons was adopted to compare the mean proportion of planthoppers infected by SBR bacterium across the three developmental insect categories. Mean proportions of SBR bacterium vertically transmitted to the insect progeny were also included for statistical comparison. ANOVA was performed by SigmaStat version 3.5 (Systat Software, Inc.) after proportions were transformed as arcsine.

Distribution and abundance of SBR bacterium within $P$. leporinus internal organs. To analyze the distribution and relative abundance of SBR bacterium within planthopper bodies, sugar beet field-collected males and females were confined singly to healthy sugar beet seedlings for an IAP of 7 days. Insects were then stored individually in separate tubes at $-80^{\circ} \mathrm{C}$. Planthoppers successful in transmitting the SBR bacterium were dissected in a drop of Ringer solution ( $\mathrm{pH}$ 7.2, Merck, Darmstadt, Germany) under a stereomicroscope by using thin forceps and pins. The midgut, entire Malpighian tubules, bacteriomes, and reproductive organs were dissected from abdomens. To isolate planthopper salivary glands, the head plus prothorax were pulled out from the meso and methathorax and then salivary glands were separated from the head of each insect. Dissected organs were individually rinsed in phosphate-buffered saline (PBS) and the DNA was extracted with a DNeasy Blood and Tissue Kit (Qiagen $\mathrm{GmbH}$, Germany) following a protocol supplied by the manufacturer. For quantitative PCR, we used a relative quantification with SYBR green I. SBR bacterium were quantified based on the accumulation of spoT PCR product relative to the planthopper 18S rRNA PCR product. Specific primers were manually designed based on the nucleotide sequence of the spoT gene of SBR bacterium, whose sequence was provided by X. Foissac (29; INRA Bordeaux, France). Forward and reverse primers were Spotf_SBR: 5'CCTATTAGAACTTCACAAGTGCAGG-3' and Spotr_SBR: 5'-AGGCAATTCGATAATTCTACCTTCG-3', respectively. We selected the $18 \mathrm{~S}$ rRNA gene from $P$. leporinus as reference gene that was obtained from sequencing the entire gene using primers and PCR procedures as described by Cryan (7). Primers, designed on the basis of obtained sequences, were 18Sf_Penta: 5'-TTCGTATTGCGACGTTAGAGGTG-3' and 18Sr_Penta: 5'-GTATCTGATCGCCTTCGAACCTC- $3^{\prime}$, respectively. Primers specificity was first tested in conventional PCR assays using DNA samples extracted from insects and sugar beets that had been previously tested for the presence of SBR bacterium by earlier described diagnostic PCR procedures $(5,31,32)$. PCR conditions were the same for both assays and included a predenaturation step at $94^{\circ} \mathrm{C}$ for $3 \mathrm{~min}$, followed by 35 cycles at $94^{\circ} \mathrm{C}$ for $30 \mathrm{~s}, 60^{\circ} \mathrm{C}$ for $30 \mathrm{~s}$, and $72^{\circ} \mathrm{C}$ for $30 \mathrm{~s}$. The final extension step was at $72^{\circ} \mathrm{C}$ for $5 \mathrm{~min}$. Obtained amplicons were sequenced to confirm they originated from the SBR bacterium spoT gene and from P. leporinus $18 \mathrm{~S}$ rRNA. Sequencing was performed by MWG GmbH (Ebersberg, Germany). Specificity was also tested with the melting curve obtained in real-time PCR assay.

Real-time PCR assays were conducted in an IQ Bio-Rad thermocycler. Reactions were carried out in a final volume of $20 \mu \mathrm{l}$ using qPCR MasterMix plus for SYBR green I (Eurogentec, Seraing, Belgium), primers were used at a final concentration of $0.25 \mu \mathrm{M}$. Seventy-five nanograms of DNA template was added to each reaction tube. Standard curves for target and reference genes were generated for each amplification run by using serially diluted DNA templates. Samples were run in duplicate. PCR cycling conditions were $50^{\circ} \mathrm{C}$ for $2 \mathrm{~min}, 95^{\circ} \mathrm{C}$ for $10 \mathrm{~min}, 40$ cycles of $95^{\circ} \mathrm{C}$ for $20 \mathrm{~s}, 60^{\circ} \mathrm{C}$ for 1 min followed by melting curve analysis from 60 to $95^{\circ} \mathrm{C}$. Crossing threshold values were calculated using Bio-Rad iCycler software. Relative SBR bacterium concentration was expressed as the ratio between target (spoT) and reference genes (18S rRNA) in each sample (dissected organ). Differences in the concentration among internal organs analyzed (midgut, Malpighian tubules, bacteriomes, salivary glands, and reproductive organs) were evaluated with the KruskalWallis test. Pairwise comparisons of homologous male and female organs were tested for differences in the bacterial concentration adopting a Mann-Whitney $\mathrm{U}$ test.

For TEM analysis, ovaries, guts, and salivary glands from four field-collected females were dissected under a stereomicroscope in a drop of PBS, transferred to a fixative solution containing glutaraldehyde $3 \%$-formaldehyde $2 \%$ in phosphate buffer, and processed as previously described (1). The remaining parts of each insect body that was not processed for TEM and included the head capsule, thorax with appendages, and remaining part of the abdomen were combined and processed for detection of SBR bacterium with PCR assay. Procedures for DNA isolation and PCR detection were as previously described (31).

\section{RESULTS}

Detection of SBR pathogens in insects and plants. We were unable to detect through specific PCR assays stolbur phytoplasma in any of the 357 planthoppers collected from the fields and tested individually, or from any sugar beet seedlings used for transmission assays. However, as specified hereafter, the same DNA templates isolated from planthoppers or sugar beet seedlings often reacted positively when tested through diagnostic PCR assays for SBR bacterium. 
Transmission assays. Transmission by nymphs. Transmission results of SBR bacterium by field-collected nymphs are reported in Table 1. One sugar beet seedling exposed to five nymphs and two seedlings exposed to 10 nymphs each, expressed foliar and tap root SBR symptoms. Detection of SBR bacterium was confirmed by PCR in the three latter plants and in one sugar beet seedling fed-inoculated with five nymphs that did not show SBR symptoms. No symptoms or detection of SBR bacterium were obtained from four non-insect-exposed sugar beets used as control. In PCR assays, 14 out of 22 nymphs (64\%) collected from sugar beet seedlings at the end of the IAP tested positive for SBR bacterium (agarose gels not shown).

Retention of infectivity. Figure 1 reports results on the retention of infectivity of SBR bacterium by field-collected females and males that were serially transferred (every three days) to healthy sugar beet seedlings. Males displayed shorter longevity than females and were less efficient in transmitting SBR bacterium to test plants (7/29) than did females (33/51). These proportions were statistically different when using a Chi-square test $\left(\chi^{2}=\right.$

TABLE 1. Transmission of syndrome "basses richesses" (SBR) bacterium by field-collected second-to-third instar nymphs of Pentastiridius leporinus

\begin{tabular}{lccc}
\hline Seedling & $\begin{array}{c}\text { No. of nymphs } \\
\text { per seedling }\end{array}$ & $\begin{array}{c}\text { PCR detection of } \\
\text { SBR bacterium }^{\mathrm{a}}\end{array}$ & $\begin{array}{c}\text { SBR symptoms } \\
\text { on test plant }^{\mathrm{b}}\end{array}$ \\
\hline 1 & 5 & + & - \\
2 & 5 & - & - \\
3 & 5 & + & + \\
4 & 10 & + & - \\
5 & 10 & + & + \\
6 & 10 & + & + \\
\hline
\end{tabular}

a $+/-$, positive/negative for polymerase chain reaction (PCR) detection.

$\mathrm{b}+/-$, presence/absence of symptoms.

\section{Days after capture (males)}

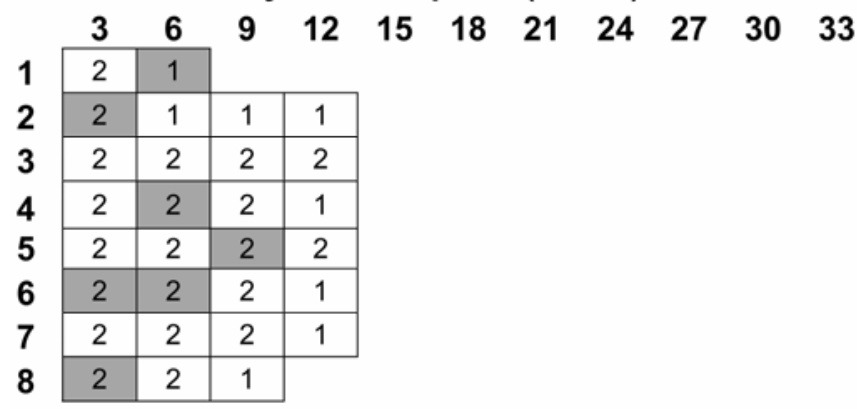

Days after capture (females)

\begin{tabular}{|c|c|c|c|c|c|c|c|c|c|c|c|}
\hline & 3 & 6 & 9 & 12 & 15 & 18 & 21 & 24 & 27 & 30 & 33 \\
\hline & 2 & 2 & 2 & 2 & & & & & & & \\
\hline & 2 & 2 & 2 & 2 & 1 & & & & & & \\
\hline & 2 & 1 & 1 & 1 & 1 & & & & & & \\
\hline & 2 & 2 & 2 & 2 & 1 & 1 & 1 & 1 & 1 & 1 & 1 \\
\hline & 2 & 2 & 2 & 2 & 2 & 2 & 1 & 1 & 1 & 1 & 1 \\
\hline & 2 & 2 & 2 & 2 & & & & & & & \\
\hline & 2 & 2 & 2 & 2 & 2 & 2 & 1 & 1 & 1 & 1 & 1 \\
\hline
\end{tabular}

Fig. 1. Transmission of the syndrome "basses richesses" bacterium to sugar beet seedlings by groups of two males or females of field-collected Pentastiridius leporinus planthoppers serially transferred every 3 days to new healthy seedlings. Each box represents an inoculated seedling with the actual number of planthoppers that fed on it. Gray is for seedlings that expressed symptoms of syndrome "basses richesses", white is for seedlings that escaped to bacterial infection. Polymerase chain reaction assays confirmed the presence or absence of syndrome "basses richesses" bacterium in inoculated plants showing symptoms.
12.17; df $=1, P<0.001)$. However, similar infection rates for SBR bacterium were obtained when analyzing individual males and females by diagnostic PCR assays. In fact, all 16 males and 14 females analyzed in PCR assays were positive for SBR bacterium. Some individual females (e.g., number 3, 4, 5, and 7; Fig. 1) were able to transmit SBR bacterium persistently and retained the inoculation ability for most of their life span, which in a few cases lasted for over 30 days. SBR bacterium were detected by diagnostic PCR assays on leaf tissues collected from seedlings showing SBR symptoms, whereas the bacterium were not detected by PCR assays on those seedlings that did not express SBR symptoms and from eight nonexposed sugar beet seedlings used as a negative control.

Vertical transmission. Results of vertical transmission assays are shown in Table 2. Despite a high death rate of nymphs maintained in captivity, adults were obtained from $F_{1}$ progenies in sufficient number to conduct transmission assays. SBR bacterium was detected in PCR assays in seven of eight parental females (Table 2). Five individuals from $F_{1}$ generation issued from the noninfected female tested negative. The sugar beet on which these individuals had fed did not develop symptoms and tested negative by diagnostic PCR assays for SBR bacterium. Conversely, SBR bacterium was detected in all $F_{1}$ progenies of infected females. Proportion of infected offspring varied from cohort to cohort and ranged from 7 to $50 \%$ with an average of $30 \%$ (Table 2). SBR symptoms appeared in plants inoculated with $F_{1}$ progenies. SBR bacterium was also detected by diagnostic PCR assays in those plants expressing SBR symptoms (Table 2) showing that vertically acquired bacteria were transmissible and pathogenic to plants. No symptoms of SBR were obtained from four nonexposed sugar beet seedlings, and these tested negative in PCR assays.

Infection of field-collected planthoppers with SBR bacterium. Out of the 357 field-collected planthoppers tested with PCR, 270 planthoppers $(75.6 \%)$ reacted positive for SBR bacterium. Figure 2 reports the mean proportion of infected planthoppers for the developmental categories considered: second-tothird instar nymphs, fourth-to-fifth instar nymphs, and emerging adults. Additionally, Figure 2 reports the mean proportion of planthoppers that vertically acquired SBR bacterium from infected parental females (above results). According to the results of vertical transmission, an average of $30 \%$ offspring acquired SBR bacterium from infected parental females. Field-collected nymphs had much higher percentage of infection than those expected by vertical transmission and averaged from $57 \%$ for early instar nymphs collected in the autumn to near $100 \%$ for old post-diapausing nymphs collected the following spring. Emerged adults had a similar percentage of infection as that obtained for late instar nymphs (Fig. 2). Means were significantly different when compared with ANOVA $(F=33.8$; df $=3,12, P<0.001)$. Except for old instar nymphs versus emerging adults, and for vertical

TABLE 2. Vertical transmission of syndrome "basses richesses" (SBR) bacterium by Pentastiridius leporinus

\begin{tabular}{lccccc}
\hline & \multicolumn{2}{c}{$\begin{array}{c}\text { PCR detection of SBR } \\
\text { bacterium on planthoppers }\end{array}$} & & & \multicolumn{2}{c}{$\begin{array}{c}\text { Test plants inoculated } \\
\text { by } \text { F }_{1} \text { generation }\end{array}$} \\
\cline { 2 - 3 } \cline { 5 - 6 } Parental \\
female & $\begin{array}{c}\text { Parental } \\
\text { female }\end{array}$ & $\begin{array}{c}F_{1} \text { generation } \\
\text { positive/tested }(\%)\end{array}$ & & $\begin{array}{c}\text { PCR } \\
\text { detection }\end{array}$ & $\begin{array}{c}\text { SBR } \\
\text { symptoms }^{\text {b }}\end{array}$ \\
\hline 1 & + & $2 / 7(28)$ & & + & + \\
2 & + & $3 / 13(23)$ & & + & + \\
3 & + & $3 / 8(37)$ & & + & + \\
4 & + & $2 / 4(50)$ & & + & + \\
5 & - & $0 / 5(0)$ & & - & - \\
6 & + & $2 / 30(7)$ & & - & - \\
7 & + & $4 / 12(33)$ & & + & + \\
8 & + & $4 / 10(40)$ & & + & + \\
\hline
\end{tabular}

a + -, positive/negative for polymerase chain reaction (PCR) detection.

$\mathrm{b}+/-$, presence/absence of symptoms. 
transmission versus second-to-third instar nymphs which did not differ statistically in average $(P>0.05)$, all other multiple pairwise comparisons differed statistically $(P<0.05)$ with a Tukey test.

Distribution and abundance of SBR bacterium within $P$. leporinus internal organs. Preliminary tests conducted with conventional PCR assays using DNA isolated from SBR-infected or healthy planthoppers and sugar beets showed that primers pairs Spotf_SBR-Spotr_SBR and 18Sf_Penta-18Sr_Penta designed for quantitative PCR were specific for the bacterium and for the planthopper, respectively. Sequencing of the obtained amplicons produced sequence readings with $100 \%$ identity for SBR bacterium spoT gene and $P$. leporinus $18 \mathrm{~S}$ rRNA. Specificity was also confirmed by melting curves analysis obtained at the end of the real-time PCR assays. We quantified the titer of SBR bacterium within organs dissected from a total of six females and seven males that were able to inoculate SBR bacterium to sugar beet seedlings. Results are shown in Figure 3. The higher concentration of the bacterium occurred within male and female reproductive organs and within female salivary glands. Significant differences were observed when the Kruskal-Wallis test was applied $(\mathrm{H}=36.5 ; \mathrm{df}=4, P<0.001)$. Reproductive organs were the most significantly infected when compared with bacteriomes and to Malpighian tubules $(P<0.05)$; however, as probably caused by the reduced number of assayed specimens (replications), no significant differences were obtained when reproductive organs were compared with salivary glands or guts $(P>0.05)$. No significant difference in the concentration of SBR bacterium was obtained by comparing homologous organs from males and females $(P>0.05$; Mann-Whitney test), except for salivary glands that were significantly more infected in females than in males $(P=0.008$; Mann-Whitney test $)$.

Portions of four female bodies processed for TEM observations resulted positive for SBR bacterium in PCR assay (agarose gel not shown). TEM observations revealed the presence of cytoplasmic rod-shaped bacteria, approximately $0.3 \mu \mathrm{m}$ in diameter and at least 2 to $2.5 \mu \mathrm{m}$ in length, in the different organs from all females analyzed. Bacteria were similar in morphology to those previously described in phloem tissues of SBR-infected sugar beets (13), and to those described for the genus Arsenophonous $(8,17)$. They were localized in the salivary gland acini (Fig. 4A) as well as in the lumen and in epithelial cells of the digestive tube (Fig. 4B). The highest density was observed in the ovarian follicular epithelium and germarium of each analyzed female (Fig.

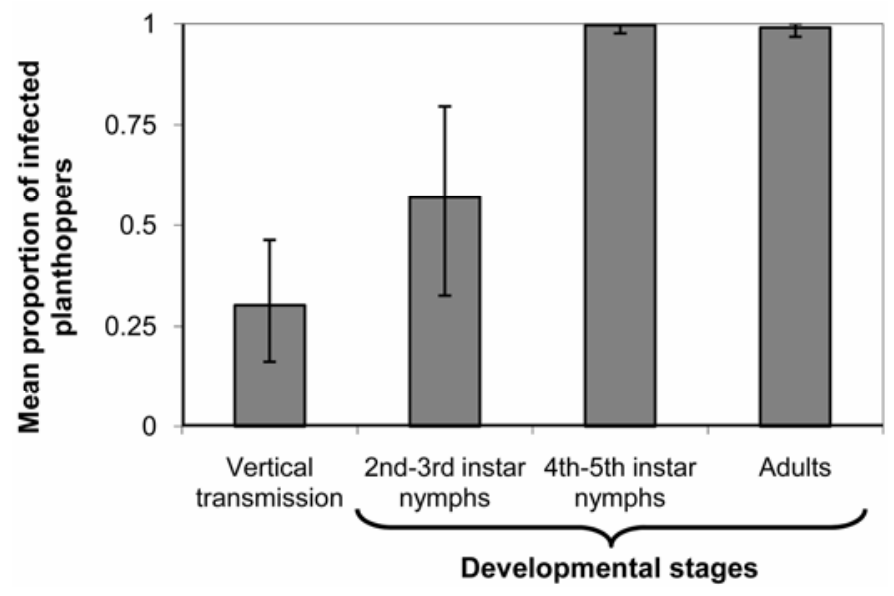

Fig. 2. Mean proportion with respective standard deviation of syndrome "basses richesses" bacterium detected by polymerase chain reaction in individual Pentastiridius leporinus collected at various moments in the season as second-to-third instar nymphs (53 tested), fourth-to-fifth instar nymphs (72 tested), or emerging adults (148 tested) from three fields rotated with sugar beet and wheat crops. Mean proportion of vertical transmission was obtained from experiment summarized in Table 2.
4C). No cytological disorders of host tissues colonized by the bacteria were noticed.

\section{DISCUSSION}

Our results showed that SBR bacterium has a complex interaction with its insect vector $P$. leporinus. Confirming previous findings $(5,31,32)$, we showed that the majority of adults collected in fields from SBR-affected areas were infected by the bacterium. However, early and pre-diapausing instar nymphs collected in the autumn had lower frequencies of infection (57\%) compared with that of post-diapausing nymphs or migrant adults at spring time for which bacterial infection reached near $100 \%$. We have shown that SBR bacterium can be vertically transmitted to the progeny of infected females, with an average of $30 \%$ of offspring carrying SBR bacterium. Thus, vertical transmission rates obtained in our experiments cannot explain the high proportion of infected planthoppers found in sugar beet fields $(5,31,32)$. Our data suggest that most of planthoppers acquire SBR bacterium by feeding as nymphs from roots of infected plants (14). Differences between the rate of infection in pre- and post-diapausing nymphs suggest that acquisition by feeding is gradual over the season and may also occur late in autumn when SBR bacterium reaches high titers within plants. It is unclear whether post-diapausing nymphs can also acquire the pathogen by feeding on sugar beet tap root debris that in some cases remain over a long period in soils and can be found in the following growing season among wheat roots.

Emerging adults, active in spreading the disease to new sugar beet plantings $(3,30)$, retain the potential of transmitting the pathogen for most of their life span. Females were more efficient in transmitting the bacterium than males that showed a discontinuous transmission pattern. This may be caused by the low titer of SBR bacterium within male salivary glands as detected in realtime PCR or by a different feeding behavior of males compared to females. However, to date there is no information published on the feeding behavior of $P$. leporinus or of other cixiid planthoppers. We have also shown that naturally infected subterraneous nymphs, including those that acquired SBR bacterium vertically from infected parental females, have the potential to inoculate the pathogen to sugar beet plants. In some unreported cases, field-collected adults experienced a high and sudden mortality when transferred within the potted sugar beet seedlings under the established greenhouse condition. In others, the possibility to collect planthopper nymphs in sufficient number was limited by their subterraneous habits. These factors have limited

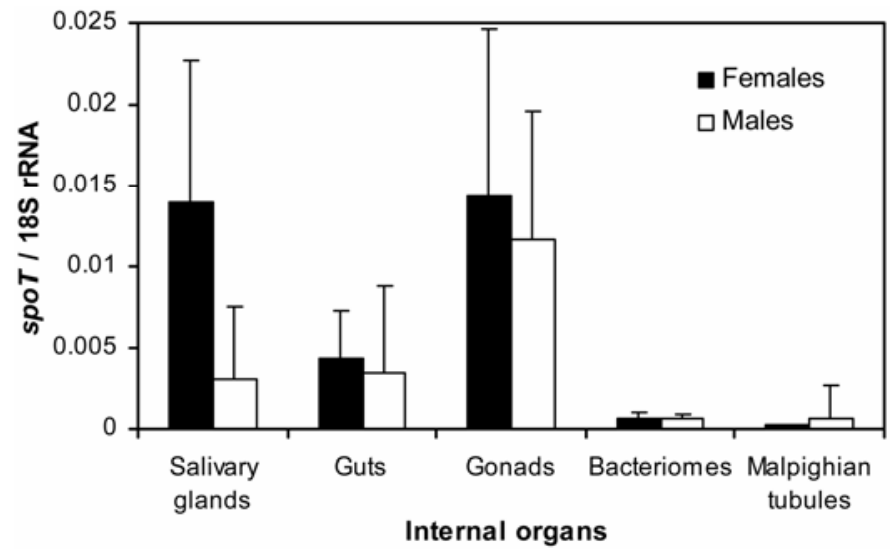

Fig. 3. Mean concentration with respective standard deviation of syndrome "basses richesses" bacterium within Pentastiridius leporinus male and female organs. Concentration is reported as ratio between accumulation of spoT and $18 \mathrm{~S}$ rRNA polymerase chain reaction products targeting syndrome "basses richesses" bacterium and Pentastiridius leporinus DNAs, respectively. Statistic analyses are reported in the text. 
our possibility to establish experiments with larger sample sizes or conduct more replications when testing for the persistence of transmission and the inoculativity of SBR bacterium by nymphs. Thus, a more accurate understanding on the transmission of SBR bacterium will benefit from further assays conducted under different environmental conditions.

According to results obtained through real-time PCR and TEM observations, SBR bacterium invades the insect haemocoel of both males and females where it colonizes in several internal organs. The higher bacterial titers were detected within female salivary glands and male and female reproductive organs. The latter finding can explain that SBR bacterium is vertically transmitted to descendants of infected planthopper females. However,
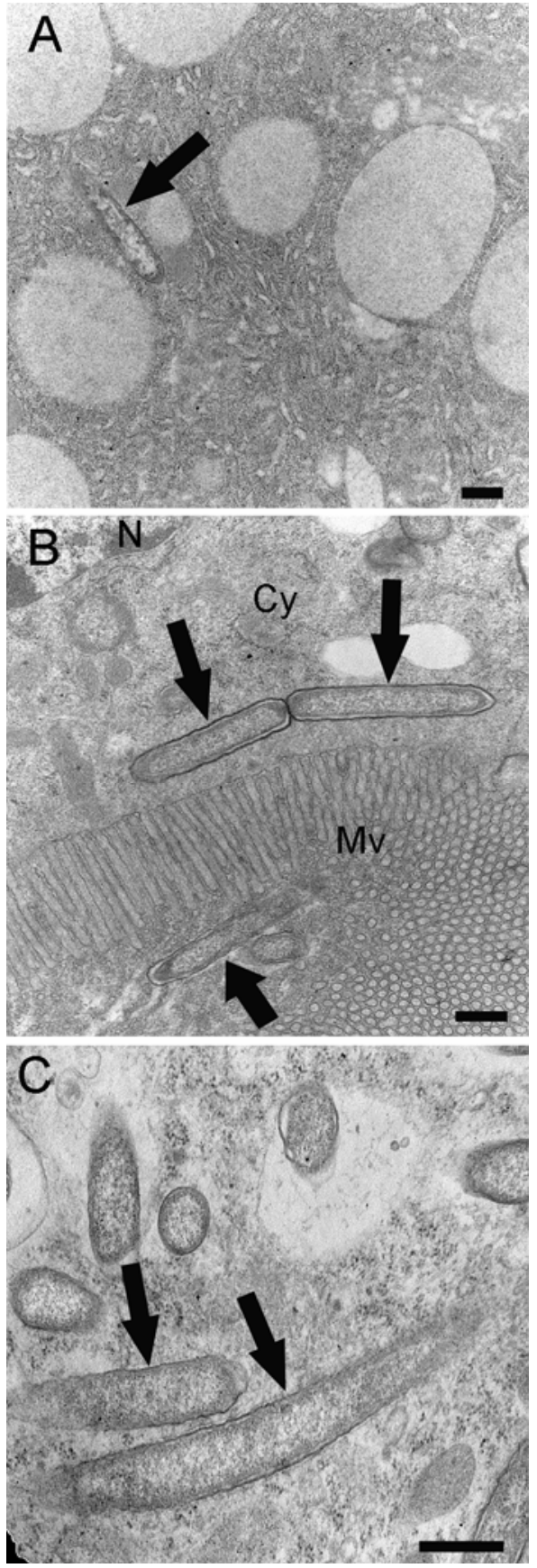

Fig. 4. Transmission electron micrographs of ultrathin sections of Pentastiridius leporinus internal organs infected by syndrome "basses richesses"like bacteria (arrows). A, Salivary gland cell. B, Midgut. N, nucleus; Cy, cytoplasm; Mv, microvilli (in longitudinal and transversal section). Note a syndrome "basses richesses"-like bacterium in the lumen (arrowhead). C, Ovarian follicular epithelium cell. thus far we do not have explanation why vertical transmission is incomplete.

In other studies, we have undertaken extensive observations on the microbial community living within $P$. leporinus haemocoel $(1,2)$. Based upon a library of eubacterial $16 \mathrm{~S}$ rRNA gene sequences obtained from DNA isolated from $P$. leporinus, we identified three bacteria other than SBR bacterium, i.e., a Wolbachia bacterium and two primary endosymbionts (2). TEM observations revealed that a bacterium with morphological features of the order Rickettsiales, which was suspected to be Wolbachia, resided within insect cell nucleus (1). In addition, both primary endosymbionts had highly derived morphology and were confined within specialized organs (2) resembling the bacteriomes described by Moran and Telang (24). In the present study, SBR bacterium was recognized in TEM of insect organs on the basis of the bacterial morphology first described within the phloem of SBR-infected sugar beets (13), and to those described within the clade Arsenophonus $(8,17)$. Thus, SBR-like bacteria could be distinguished from the other three symbiotic bacteria based upon their differential morphology and distribution. Interestingly, no cytological abnormalities were noticed in insect tissues infected by SBR-like bacteria.

Both techniques adopted in this research to localize and quantify SBR bacterium have some possible downsides. For instance, salivary glands and reproductive organs are made up of larger cells compared to other insect organs and this may have yield to a lower amount of $18 \mathrm{~S}$ rRNA product in real-time PCR overestimating bacteria from those organs. The identification of SBR bacterium by TEM was solely based upon cell morphology which does not provide warranties about the real identity of the bacterium, whose morphology is similar to other $\gamma-3$ proteobacteria. To data, no antibodies are available for SBR bacterium and this limit the possible application of any immunolabeling assays. Thus we are exploring the possibility to further investigate the relationship between SBR bacterium and its insect vector by using fluorescence in situ hybridization (FISH) assays adopting probes to hybridize specifically with $16 \mathrm{~S}$ rRNA sequence of the bacterium. Hopefully this technique will permit us to analyze the possible presence of SBR bacterium with planthoppers, including the foreguts, which are reported in literature as a major retention site for insect-transmitted xylem-limited bacteria and viruses.

Because SBR bacterium was consistently detected in nymphs and adults of $P$. leporinus over its whole life span, in comparison with the short cycle of sugar beet crop, the bacterium seems to spend most of its life cycle in association with the insect rather than within the plant. In fact, sugar beet is cultivated on a springautumn basis, sowed by March and harvested in October. A likely scenario based on outcomes from our experiments and previous reports $(3,13,14,32)$ assumes that planthoppers inoculate plants from the end of June through July, after migration to sugar beet crops. SBR bacterium can be acquired by nymphs hatched from eggs laid close to sugar beet roots, either through vertical maternal transmission or during feeding on tap roots of plants infected by the parental generation. Thus, SBR bacterium would reside roughly for 3 to 4 months (July to October) within sugar beets and almost for the whole year including the winter season, within planthoppers. Because of vertical transmission, SBR bacterium would have the potential to survive multiple years without being transmitted to plants. This is important when emergence of a new disease focus is considered, since no other cultivated or wild plant could be found infected with SBR bacterium in the areas concerned by SBR disease (12,31).

SBR bacterium shows common ecological traits with both arthropod-specialized secondary symbionts (26; e.g., near fixation in insect host populations, vertical transmission, distribution within insect reproductive organs, absence of apparent cytological damage to colonized insect host cells) and plant-pathogenic phloem-restricted bacteria obligatorily transmitted by insect vec- 
tors $(20,21)$. Hence, our data suggest that $P$. leporinus is the primary host for SBR bacterium. In accordance to this hypothesis, SBR bacterium is phylogenetically placed within the Arsenophonus clade, which contains mostly bacteria described as secondary symbionts of insects $(6,8,19,37)$.

It is clear from earlier reports that SBR bacterium is pathogenic to plants $(5,13,32)$. However, it has not been investigated how the bacterium might affect the fitness of its insect host. Arsenophonus bacteria can cause a range of phenotypic effects spanning from manipulation of insect host reproduction to mutualism (26). For instance, Arsenophonus nasoniae induces male killing in the wasp Nasonia vitripennis, a parasitoid of several fly species (16); however, SBR bacterium does not seem to cause sex-ratio distortion as $P$. leporinus populations have a balanced sex ratio $(12,30)$. Other studies have suggested that Arsenophonus caused adaptation of whiteflies to specific host plants (6) or displayed a potential protective role to parasitoid attack of an invasive psyllid in California (19).

It should be examined if SBR bacterium confers a selective advantage to infected planthoppers. Although in certain cases, planthoppers from the genus Pentastiridius have been found to colonize disturbed and ruderal habitats (27), it is still unclear how $P$. leporinus successfully colonized sugar beet and wheat fields only in eastern France where it can establish very large populations $(3,5,12,30)$. The success of the planthopper is probably associated with the ability to survive the crop rotation, and in particular the change of host plant. In fact, if a species can not overwinter in the same field after harvesting, it will rapidly come to near extinction in agricultural systems. Thus, it is possible that SBR bacterium provides infected planthoppers with a selective advantage to colonize and live between sugar beet and wheat crops. Such an advantage would account for the high infection rate with the bacterium of $P$. leporinus populations living in the cropping system.

Similar to Arsenophonus bacteria that are secondary symbionts of insects, and to phloem-restricted prokaryotes transmitted obligatorily by insect vectors (20), SBR bacterium also has the potential of being transmitted and hosted by species of insects other than $P$. leporinus. In fact, in a previous study (5) we have obtained evidence of SBR bacterium transmission by specimens of another planthopper cixiid, $C$. wagneri that were collected from heavily SBR-affected sugar beet fields. We suggested that $C$. wagneri planthoppers were able to acquire SBR bacterium by feeding from SBR-infected plants (5). Nevertheless, in another previous survey we failed to detect SBR bacterium within 24 other hemipterous insects collected from a SBR-affected sugar beet area (31), which may suggest that the bacterium is specific to cixiid planthoppers.

This is the first study that focuses on the relationship between a plant pathogenic bacterium in the Arsenophonus clade and its insect vector. Although several aspects have been investigated, outcomes from our research bring up new questions that need to be addressed in order to understand factors that drive the emergence and epidemiology of plant diseases associated with such prokaryotes. Among the many questions, we think it is important to understand how SBR bacterium might affect the insect host fitness, how root feeding specialization might favor the acquisition of phloem-restricted pathogens, what mechanisms regulate vertical transmission, and whether SBR bacterium could be sexually transmissible, since literature has reported sexual transmission of both secondary bacteria of aphids (25) and a plant virus in whiteflies (15).

\section{ACKNOWLEDGMENTS}

We thank X. Foissac for providing sequences of the gene spoT of the SBR bacterium and C. H. V. Higashi for comments and revision of the manuscript. This work was supported by the Institut technique de la betterave industrielle (ITB) and the Conseil Régional de Bourgogne.

\section{LITERATURE CITED}

1. Arneodo, J. D., Bressan, A., Lherminier, J., Michel, J., and BoudonPadieu, E. 2008. Ultrastructural detection of an unusual intranuclear bacteria in Pentastiridius leporinus (Hemiptera: Cixiidae). J. Invertebr. Pathol. 97:310-313.

2. Bressan, A., Arneodo, J. D., Simonato, M., Haines, W. P., and BoudonPadieu, E. Characterization and evolution of two bacteriome-inhabiting symbionts in cixiid planthoppers (Hemiptera: Fulgoromorpha: Pentastirini). Environ. Microbiol. (In Press.)

3. Bressan, A., Moral García, F. J., Sémétey, O., and Boudon-Padieu, E. Spatio-temporal patterns of Pentastiridius leporinus migration in an ephemeral cropping system. Agric. For. Entomol. (In Press.)

4. Bressan, A., Nusillard, B., Holzinger, W. E., Sémétey, O., Gatineau, F., Simonato, M., and Boudon-Padieu, E. 2009. Identification and biological traits of a planthopper from the genus Pentastiridius (Hemiptera: Cixiidae) adapted to an annual cropping rotation. Eur. J. Entomol. 106:405-413.

5. Bressan, A., Sémétey, O., Nusillard, B., Clair, D., and Boudon-Padieu, E. 2008. Insect vectors (Hemiptera: Cixiidae) and pathogen types associated with syndrome "basses richesses" disease of sugar beet in France. Plant Dis. 92:113-119.

6. Chiel, E., Gottlieb, Y., Zchori-Fein, E., Mozes-Daube, N., Katzir, N., Inbar, M., and Ghanim, M. 2007. Biotype-dependent secondary symbiont communities in sympatric populations of Bemisia tabaci. Bull. Entomol. Res. 97:407-413.

7. Cryan, J. R. 2005. Molecular phylogeny of Cicadomorpha (Insecta: Hemiptera: Cicadoidea, Cercopoidea and Membracoidea): Adding evidence to the controversy. Syst. Entomol. 30:563-574.

8. Dale, C., Beeton, M., Harbison, C., Jones, T., and Pontes, M. 2006. Isolation, pure culture, and characterization of "Candidatus Arsenophonus arthropodicus", an intracellular secondary endosymbiont from the hippoboscid louse fly Pseudolynchia canariensis. Appl. Env. Microbiol. 72:2997-3004.

9. Danet, J.-L., Foissac, X., Zreik, L., Salar, P., Verdin, E., Nourrisseau, J. G., and Garnier, M. 2003. "Candidatus Phlomobacter fragariae" is the prevalent agent of marginal chlorosis of strawberry in French production fields and is transmitted by the planthopper Cixius wagneri (China). Phytopathology 93:644-649.

10. Firrao, G., Gibb, K., and Streten, C. 2005. Short taxonomic guide to the genus "Candidatus Phytoplasma". J. Plant Pathol. 87:249-263.

11. Foissac, X., Danet, J.-L., Zreik, L., Gandar, J., Nourrisseau, J.-G., Bové, J. M., and Garnier, M. 2000. Cloning of the spoT gene of "Candidatus Phlomobacter fragariae" and development of a PCR-restriction fragment length polymorphism assay for detection of the bacterium in insects. Appl. Env. Microbiol. 66:3474-3480.

12. Gatineau, F. 2002. Rôle Etiologique du Phytoplasme du Stolbur et d'un Bacterium-Like Organism (BLO) dans le Syndrome des Basses Richesses (SBR) de la Betterave Sucrière (Beta vulgaris L.). Epidémiologie de la Maladie et Biologie du Vecteur Identifié, le Cixiide Pentastiridius beieri, Wagner. Ph.D. Thesis. Université de Bourgogne, Dijon, France.

13. Gatineau, F., Jacob, N., Vautrin, S., Larrue, J., Lherminier, L., RichardMolard, M., and Boudon-Padieu, E. 2002. Association with the syndrome "basses richesses" of sugar beet of a phytoplasma and a bacterium-like organism transmitted by a Pentastiridius sp. Phytopathology 92:384-392.

14. Gatineau, F., Larrue, J., Clair, D., Lorton, F., Richard-Molard, M., and Boudon-Padieu, E. 2001. A new natural planthopper vector of stolbur phytoplasma in the genus Pentastiridius (Hemiptera: Cixiidae). Eur. J. Plant Pathol. 107:263-271.

15. Ghanim, M., and Czosnek, H. 2000. Tomato yellow leaf curl geminivirus (TYLCV-Is) is transmitted among whiteflies (Bemisia tabaci) in a sexrelated manner. J. Virol. 74:4738-4745.

16. Gherna, R. L., Werren, J. H., Weisburg, W., Cote, R., Woese, C. R., Mandelco, L., and Brenner, R. 1991. Arsenophonus nasoniae, genus novel, species novel, causative agent of son killer trait in the parasitic wasp, Nasonia vitripennis. Int. J. Syst. Bacteriol. 41:563-565.

17. Gottlieb, Y., Ghanim, M., Gueguen, G., Kontsedalov, S., Vavre, F., Fleury, F., and Zchori-Fein, E. 2008. Inherited intracellular ecosystem: Symbiotic bacteria share bacteriocytes in whiteflies. FASEB J. 22:2591-2599.

18. Hanboonsong, Y., Choosai, C., Panyim, S., and Damak, S. 2002. Transovarial transmission of sugarcane white leaf phytoplasma in the insect vector Matsumuratettix hirogliphicus (Matsumura). Insect Mol. Biol. 11:97-103.

19. Hansen, A. K., Jeong, G., Paine, T. D., and Stouthamer, R. 2007. Frequency of secondary symbiont infection in an invasive psyllid relates to parasitism pressure on a geographic scale in California. Appl. Environ. Microbiol. 73:7531-7535.

20. Hogenhout, S. A., Oshima, K., Ammar, E.-D., Kakizawa, S., Kingdom, H. N., and Namba, S. 2008. Phytoplasmas: Bacteria that manipulate plants and insects. Mol. Plant Pathol. 4:403-423. 
21. Hung, T. H., Hung, S. C., Chen, C. N., Hsu, M. H., and Su, H. J. 2004. Detection by PCR of Candidatus Liberibacter asiaticus, the bacterium causing citrus Huanglongbing in vector psyllids: Application to the study of vector-pathogen relationships. Plant Pathol. 53:96-102.

22. Lefol, C., Lherminier, J., Boudon-Padieu, E., Larrue, J., Louis, C., and Caudwell, A. 1994. Propagation of the Flavescence dorée MLO (mycoplasma-like organism) in the leafhopper vector Euscelidius variegatus Kbm. J. Invertebr. Pathol. 63:285-293

23. Lherminier, J., Prensier, G., Boudon-Padieu, E., and Caudwell, A. 1990. Immunolabeling of grapevine Flavescence dorée MLO in salivary glands of Euscelidius variegatus: A light and electron microscopy study. J. Histochem. Cytochem. 38:79-89.

24. Moran, N. A., and Telang, A. 1998. The evolution of bacteriocyteassociated endosymbionts in insects. Bioscience 48:295-304.

25. Moran, N. A., and Dunbar, H. E. 2006. Sexual acquisition of beneficial symbionts in aphids. PNAS 103:12803-12806.

26. Moran, N. A., McCutcheon, J. P., and Nakabachi, A. 2008. Genomics and evolution of heritable bacterial symbionts. Annu. Rev. Genet. 42:165-190.

27. Nickel, H. 2003. The leafhoppers and planthoppers of Germany (Hemiptera, Auchenorrhyncha): Patterns and Strategies in a Highly Diverse Group of Phytophagous Insects. Pensoft, Sofie-Moscow.

28. Russell, J. A., Latorre, A., Sabater-Munoz, B., Moya, A., and Moran, N. A. 2003. Side-stepping secondary symbionts: Widespread horizontal transfer across and beyond the Aphidoidea. Mol. Ecol. 12:1061-1075.

29. Salar, P., Sémétey, O., Danet, J.-L., Boudon-Padieu, E., and Foissac, X. 'Candidatus Phlomobacter fragariae' and the proteobacterium associated with the low sugar content syndrome of sugar beet are related to bacteria of the arsenophonus clade detected in hemipteran insects. Eur. J. Plant Pathol. (In Press.)

30. Sémétey, O. 2006. Syndrome des basses richesses de la betterave sucrièrecaractérisation de la protéobactérie associée, biologie et vection. Perspectives de lutte. Ph.D. thesis. Université de Bourgogne, Sciences de la Vie et de la Santé, Dijon, France.

31. Sémétey, O., Bressan, A., Gatineau, F., and Boudon-Padieu, E. 2007. Development with RISA of a specific assay for detection of the bacterial agent of syndrome "basses richesses" of sugar beet. Confirmation of Pentastiridius sp. (Fulgoromopha, Cixiidae) as the economic vector. Plant Pathol. 56:797-804.

32. Sémétey, O., Bressan, A., Richard-Molard, M., and Boudon-Padieu, E. 2007. Monitoring of proteobacteria and phytoplasma in sugar beet naturally or experimentally affected by the disease syndrome "basses richesses". Eur. J. Plant Pathol. 117:187-196.

33. Sémétey, O., Gatineau, F., Bressan, A., and Boudon-Padieu, E. 2007. Characterization of a $\gamma-3$ proteobacteria responsible for the syndrome "basses richesses" of sugar beet transmitted by Pentastiridius sp. (Hemiptera: Cixiidae). Phytopathology 97:72-78.

34. Tanaka, M., Nao, M., and Usugi, T. 2006. Occurrence of strawberry marginal chlorosis caused by 'Candidatus Phlomobacter fragariae' in Japan. J. Gen. Plant Pathol. 72:374-377.

35. Tedeschi, R., Ferrato, V., Rossi, J., and Alma, A. 2006. Possible phytoplasma transovarial transmission in the psyllids Cacopsylla melanoneura and Cacopsylla pruni. Plant Pathol. 2006:18-24.

36. Terlizzi, F., Babini, A. R., Lanzoni, C., Pisi, A., Credi, R., Foissac, X., and Salar, P. 2007. First report of a $\gamma-3$ proteobacterium associated with diseased strawberries in Italy. Plant Dis. 91:1688.

37. Thao, M. L., and Baumann, P. 2004. Evidence for multiple acquisition of Arsenophonus by whitefly species (Sternorrhyncha: Aleyrodidae). Curr. Microbiol. 48:140-144.

38. Weintraub, P. G., and Beanland, L. 2006. Insect vectors of phytoplasmas. Annu. Rev. Entomol. 51:91-111.

39. Zreik, L., Bové, J. M., and Garnier, M. 1998. Phylogenetic characterization of the bacterium-like organism associated with marginal chlorosis of strawberry and proposition of a Candidatus taxon for the organism, "Candidatus Phlomobacter fragariae". Int. J. Syst. Bacteriol. 48:257-261. 